\title{
The Diplomacy of Quasi-State in the Territorial Disputes: Taiwan in the South China Sea
}

\author{
Sukmawani Bela Pertiwi \\ Department of International Relations, Bina Nusantara University, Jakarta, Indonesia \\ bela.pertiwi@gmail.com
}

\section{Luh Nyoman Ratih Wagiswari Kabinawa}

Department of International Relations, Bina Nusantara University, Jakarta, Indonesia nyoman.ratih@gmail.com

\section{Rangga Aditya Elias}

Department of International Relations, Bina Nusantara University, Jakarta, Indonesia raaditya@binu.edu

Submitted: 1 October 2019; Revised; 13 November 2019; Accepted: 24 February 2020

\begin{abstract}
Abstrak
Artikel ini bertujuan menganalisis diplomasi sebuah quasi-state dalam sengketa wilayah dengan menggunakan studi kasus Taiwan di Laut Cina Selatan. Quasi-state bukan merupakan diskusi yang banyak diangkat dalam Hubungan Internasional sehingga konsep dan teorinya pun belum berkembang secara baik. Meskipun demikian, dengan perkembangan globalisasi, keberadaan quasi-state menjadi semakin terlihat, dan banyak diantaranya terlibat dalam sengketa yang solusinya memerlukan pemahaman tentang quasi-state tersebut, seperti yang terjadi di Laut Cina Selatan. Artikel ini berargumen bahwa quasi-state memiliki kelemahan legal dan politik sehingga diplomasi quasi-state dapat dilihat dengan menggunakan teori-teori diplomasi negara lemah, seperti diplomasi multi jalur untuk mengatasi kelemahan legalnya dan strategi hedging untuk mengatasi kelemahan politiknya. Menggunakan pendekatan kualitatif berdasarkan sumber primer dan sekunder tentang evolusi kebijakan Taiwan di Laut Cina Selatan, artikel ini berkesimpulan bahwa diplomasi Taiwan di Laut Cina Selatan pun mengikuti pola yang sama. Kata Kunci: diplomasi, quasi-state, sengketa wilayah, Taiwan, sengketa Laut Cina Selatan.
\end{abstract}

\begin{abstract}
This study aims to examine the diplomacy of quasi-state in a territorial dispute by using the case of Taiwan in the South China Sea. The discussion on quasi-state is not mainstream in International Relations, and thus its concept and theories are not well developed. By the rise of globalization, however, quasi-states have a more active presence and that many parties involved in conflicts which resolutions require understanding on quasi-state, including the South China Sea Disputes. This paper argues that quasi-state suffers from legal and political weaknesses, and consequently, the diplomacy of quasi-state could be examined using theories on the diplomacy of weak states which include multitrack diplomacy to deal with its legal weaknesses and hedging to deal with its political shortcomings. Employing a qualitative method based on primary and secondary sources on Taiwan evolving policy on the South China Sea, this paper found that the diplomacy of Taiwan in the South China Disputes also follows this pattern.

Keywords: diplomacy, quasi-state, territorial disputes, Taiwan, South China Sea disputes.
\end{abstract}

\section{INTRODUCTION}

Quasi-state, known as "pseudo states", "de facto states" or "unrecognized state" is not a mainstream discussion in International Relations (IR) (Kolossov \& O'Loughlin, 1998; Pegg, 1998; Kolsto, 2006). There are studies on the individual state, but they are scattered and focus on explaining the particular case study itself without building a systematic and coherent approach to study this case within the framework of quasi-state. On the one hand, it is well understood given that most of these states emerge from separatist movements of the existing state - a process that is contentious and often opposed by many as it is against the internationally 
accepted norms of sovereignty and territorial integrity. Thus, the lack of discussion on quasi-state, at this point, mainly because it is not part and against the preservation of the state system itself. The core concept in IR diplomacy - for example, entails the specific reference to state conduct in dealing with other states in searching for conflict resolution. Thus, as Fiona McConnell, Terri Moreau, and Jason Dittmer point out, the term also strengthens "the discourse of recognition and authority (re)performed by sovereign states to exclude non-sovereign others" and thus making discussion on quasi-state even submerged (McConnel, Moreau, \& Dittmer, 2012).

On the other hand, however, this lack of knowledge accumulation on a quasi-state is a disadvantage because as a separate category of an actor in IR, quasi-state has unique characteristics that make their behavior also unique compared to state actors. Many have explored the legal consequences of quasi-state in which these states have no formal recognition from other countries, limited access to the inter-governmental results, and limited access to an international agreement. However, few in IR have explored the political consequences from these legal circumstances as to how do these states conduct "quasi-diplomacy" with state actors to achieve their goal in the absence of all the access as mentioned above? This question is not only interesting but also valuable to understand the behavior of quasi-states with a total of 34 states or almost one-fifth of the total number of states based on calculation from 1945 to 2011 as the latest dataset indicated (Florea, 2014). The question of quasi-state is even more critical especially in the current globalization era whereby this process has offered opportunities for new and non-state actors, to play a more significant role in the previously dominated interstate system. Quasi-state, which principally fulfils the criteria of statehood but only misses recognition from others, are also becoming more active in various international affairs for their survival both through vast economic cooperation and continuous political engagement. Their presence, therefore, could no longer be ignored. Moreover, quasi-state, for their purpose of gaining recognition or due to their legal exclusion from the international system (Grzybowski, 2019), often involved in various conflicts with other parties, many of which are still outstanding and kill thousands of people. In fact, many of these conflicts are unsettled or become more complicated as it involves these quasi-states. Conflict resolution, therefore, requires an understanding of the behavior of quasi-states.

Take the most evident example, which would also be the focus of this paper, the South China Sea disputes. The South China Sea dispute is not as bloody as other conflicts involving quasi-states. However, this dispute is among the most long-standing and contentious debates in Southeast Asia, which have global consequences. First of all, the South China Sea, as the disputed area is one of the most important hubs in the global maritime trade route connecting the rapidly developed East Asian economies to the global market. It is estimated that a quarter of the global maritime trade passes this area each year (Ba, 2011) among which for exporting half of the global oil and two-third of the global natural gas (Johnson, 2012). This oil volume, for comparison, is sixteen times more than those carried through the Panama Canal, and also one of the busiest hubs for global maritime trade (Johnson, 2012). It is not surprising, therefore, that even though the dispute never peaked into open military confrontation since 1988 , the situation is always contentious with global powers such as the United States, India, Japan, and Russia also interfering in the disputes in varying degree. It has not mentioned the economic significance of this area in relations to its non-living resources such as oil and natural gas reserve estimated to be more than 200 billion barrels (Johnson, 2012) and living resources in the form of fishing stocks accounted as much as 12 percent of the total global catch (Greer, 2016).

Second, the dispute is also contentious because China, the second most powerful state in the world, which is also regarded as the closest substitute for the declining American power is also a claimant in the dispute. In fact, it is not only the biggest claimant state in the dispute but also has the most significant claimed territory. Consequently, many watch the South China Sea as the test case that has the potential to alter the balance of power in the region. Given the above mentioned economic importance of the South China Sea and its importance for China's strategic defence, the prospect of China's controlling the South China Sea is an alert for the United States and other maritime powers 
who have a stake on navigation and sea lane of communication in this sea. In addition, the dispute is also a test case for reading typical China's leadership style should it be a global power in the future. China's conduct in the South China Sea, in this case, is perceived as a test case to identify if it is a benign rising power that could manage dispute peacefully with others, or it is a unilateral assertive power which is likely to interfere its much smaller neighboring countries surrounding the South China Sea. In either case, China's participation in the dispute has complicated the existing territorial disputes with power politics which make a confidence-building and dispute settlement even more difficult.

Based on the above circumstances, it is well understood that the dispute attracts wide attention with a large number of pieces of literature mostly focusing on the critical role of China in shaping the dynamics of the dispute from its different approach towards other claimants states to its divisive attitude toward other ASEAN members in the regional dispute management mechanism (Fravel, 2011; Kim, 1998; Thayer, 2012; Goldstein, 2011; Swaine \& Fravel, 2011). Other pieces of literatures have also discussed extensive contrary, that is, how each individual claimant state and even outside powers deal with China in the dispute (de Castro, 2009; Sutter, 2010; Thayer, 2011; Buszynski, 2012; Storey, 2008). These vast pieces of literatures, however, address little about Taiwan, which is, despite its quasi-state status, also a claimant to the dispute. In one part, it is reasonable that Taiwan is a small entity, and its claim is similar to China, and thus no contention occurs with the most powerful claimant state. Its status as a quasi-state also implies that it is not recognized as a party to any first track diplomacy of dispute management in the South China Sea due to other countries' adherence to one China Policy.

However, dismissing the importance of Taiwan in the dispute would undermine the prospect for dispute settlement. First of all, Taiwan, regardless of its quasi-state status, is a claimant to the conflict, and thus no dispute settlement would be achieved without Taiwan. Second, Taiwan has claimed, occupied, and equipped the largest island in the South China Sea - Itu Aba militarily - and thus, its position is critical in the negotiation of any maritime delimitation in Spratlys (Kuok, 2015). Moreover, it is due to its large claim in the dispute that Taiwan would take a necessary measure to defend its claim. Taiwan also has the second largest fishing fleet in the world (Wang, 2018) which would not only strengthen Taiwan's position in defending its claim in the dispute but also would have the potential to set the dynamics of the dispute. Taiwan is also backed by the United States, which would make the dispute more contentious vis a vis China. Finally, Taiwan is essential as it is the only actor that could undermine China's excessive claim in the dispute through its ambiguous nine-dashed-line map covering the entire South China Sea. It is this excessive claim and China's stern position not to clarify this claim that makes South China dispute more intractable. In this regard, the fact that Taiwan has a similar claim with China because they argue to be the legitimate representative of China indicating that Taiwan could undermine China's claim should it decide to clarify its own claim in the dispute (Kuok, 2015). However, Taiwan could also shift the power balance in favor of China should it decide to align with China in the dispute. In short, Taiwan is a strategic player in the South China Sea dispute, and it is for all these reasons that this research paper aims to examine Taiwan strategy in the South China Sea disputes as to how Taiwan as a quasi-state conducts diplomacy to defend its claim in the South China Sea.

In doing so, this paper is structured in two parts. The first part is the theoretical framework, where it discusses the concept of quasi-state and develops an analytical framework for examining the diplomacy of quasi-state. The second part is the case study, where it begins to apply this framework in the case study of Taiwan in the South China Sea disputes. This section provides the context of the South China Sea Disputes and Taiwan's strategic interest in the dispute and then examines the diplomacy of Taiwan as a quasi-state in the dispute, which leads to a conclusion. As it is a case study research, this paper will mainly adopt a qualitative method to understand better the practice of diplomacy of a quasi-state in the case of Taiwan. In terms of the theoretical part, this paper will explore various academic sources to build on the existing research. Meanwhile, in terms of the case study part, this paper consults both primary sources from Taiwan government's documents and website and secondary sources from media or academic journal articles to enrich the data for the case explanation. 


\section{THEORETICAL FRAMEWORK CONCEPTUALIZING QUASI STATE}

The first step of explaining the diplomacy of Taiwan as a quasi-state would require the development of an analytical framework for the quasi-state itself. The phrase 'development of analytical framework' here is intentional, given that the concept of quasi-state is ill-defined, and no theories have been developed to explain the diplomacy of quasi-state. In regards to the former, principally, there is an agreement that quasi-state is a concept to describe entities counted as "almost states" (Kolsto, 2006). However, scholars differ significantly on which aspects that make them "almost states". According to Robert H. Jackson who coined the term in 1990 through his mostly referred book on Quasi State entitled "Quasi States: Sovereignty, International Relations, and the Third World", explaining that quasi-state is entities recognized as states, but it could not perform its statehood in practice. Here he used the term quasi-state to describe ex-colonial states in the third world who gain recognition as independent states after the decolonization process. Thus they accept 'juridical statehood' defined as possessing "the same external rights and responsibilities like all other sovereign states." These states, however, "have not yet been authorized and empowered domestically and consequently lack institutional features of sovereign states as also defined by classical international law" (Jackson, 1990). In other words, these states lack 'empirical statehood' whereby the citizens do not enjoy the benefit of independent states, and the government does not provide sufficient public goods (Jackson, 1990).

Due to this definition, the concept of quasi-state developed by Jackson overlaps with the concept of failed states, which are later becoming more popular. This concept is also used to include "an entity that aspires to statehood or fights for a statehood issue, that even controls statehood functions, but that is not a sovereign state" (Dijxhoorn, 2017) - a definition which also overlaps with the concept of rebels or separatism. It is for this reason that this paper adopts the alternative meaning of quasi-state proposed by Kolsto which principally focuses on to describe the opposite group of the phenomenon that is an entity that has met criteria for statehood but "lack international recognition" (Kolsto, 2006). Whether this state in practice is weak or not is not subject to debate in this definition as its emphasis is on the absence or lack of recognition from others, which makes the way of these states in pursuing its interest unique and different from others. This lack of recognition itself is the result of combination of various factors, from legal, in which the process leading to the formation of these states is frequently seen as against the norm of territorial integrity, to political reason in which it is against the will of the "parent" state, and recognizing quasi-state might have political risk for countries which also have secessionist movements.

Based on this explanation, this definition, therefore, is similar to what Scott Pegg (Pegg, 1998) refers to as "de facto states" or what Nina Caspersen refers to as "unrecognized states" (Caspersen, 2012). The first refers to a "secessionist entity that receives popular support and has achieved sufficient capacity to provide governmental services to a given population in a defined territorial area, over which it maintains effective control for an extended period" (Pegg, 1998). Meanwhile, the latter refers to entities that "have achieved de facto independence, including territorial control", "have not gained international recognition", and "have demonstrated an aspiration for full, de jure, independence" (Caspersen, 2012). The number of this category of the state itself differs across datasets depending on which definition they refer to. Caspersen, for example, mentions there are 17 unrecognized states since 1991 (Caspersen, 2012). Meanwhile, Douglas Lemke's dataset (Lemke, 2017) indicates there are 187 de facto states from 1816 to 2010 or 34 countries from 1945-2011, according to Florea's dataset (Florea, 2014). Examples of these states, among others, are Abkhazia, Chechnya, Nagorno Karabakh, South Ossetia, Somaliland, Transnistria and Taiwan.

The following question is, what is the consequence of being quasi-state or unrecognized by other states? The existing literature has extensively discussed the legal circumstance of quasi-state in three areas (deLisle, 2011; Henckaerts, 1996; Dijxhoorn, 2017; Chiang, 2018). First of all, quasi-states have only limited diplomatic relations with other states. In the case of Taiwan, the increasing power of China, followed by the 1971 UN Resolution which granted the seat of China in the UNSC to PRC, has become a turning point for other countries to switch 
their diplomatic relations from Taiwan to the PRC. The only 24 states left to maintain their recognition of Taiwan, all of which are not significant global players. By the continuously rising China's power in global affairs, other countries become more reluctant to break their commitment to One China Policy. Consequently, Taiwan could only maintain modest diplomatic relations with other states in a less informal way, such as being apparent in their Representative Offices instead of Embassies to other countries. This relation is also mainly to maintain economic ties in which Taiwan has more leverage as the world's 15th most competitive economy in 2017 (Taiwan Today, 2017) and the fifth-largest foreign exchange reserve holder in 2018 (Central Intelligence Agency, 2018). In countries to which Taiwan has close relations such as the United States, there have been special arrangements for compensating and maintaining bilateral relations. The US government, for example, has enacted Taiwan Relations Act (TRA) which stipulates that no changes occur concerning people's contacts and domestic law resulting from the US switching commitment to One China Policy (Pegg, 1998).

The second legal circumstance is that quasi-states have only limited access to international organizations (deLisle, 2011). Quasi-states indeed have access to an international organization whose members are not exclusive states, such as WTO, APEC, ICAO, and WHA. However, the largest and perhaps most crucial international body, that is the United Nations (UN), along with its agencies is an exclusive state membership that makes quasi-state membership difficult. Quasi-state indeed could pursue argument demonstrating their statehood or the UN practice, which enables some cases of quasi-states for joining the UN in the past (de Lisle, 2011). However, in the case of Taiwan, it is still challenging as it has China in its Security Council, which is ready to veto against Taiwan membership at any time of its application. Taiwan's strategy so far, therefore, include pursuing non-member status and taking opportunity where possible in any UN treaties and activities (de Lisle, 2011).

Lastly, concerning this situation, quasi-states also have limited access to international law, court, and agreement (Hsieh, 2007). The International Court of Justice, at this point, is the primary judicial body of the United Nations. As Pasha L. Hsieh (Hsieh, 2007) pointed out, however, it has jurisdiction only to members of the ICJ statute in which Taiwan is not a member and would be very difficult to be one as it needs a recommendation from the Security Council in which China is, again, a member. Taiwan could use the provision for non-statutory state whereby they could confer their disputes to ICJ. However, Taiwan has never used this option to the high risk of losing the case in front of the most referred Court and that others will follow (Hsieh, 2007). Hsieh also pointed out that the situation is slightly different in regards to the Law of the Sea, which is not an exclusive state membership and Taiwan gains special recognition as a fishing entity under this Law. It means that Taiwan, here, also has access to International Tribunal on the Law of the Sea (ITLOS) as the dispute settlement body of the UNCLOS whenever it has maritime disputes with other states - cases which potentially occur frequently given Taiwan status as among the top ten fishing industry in the world. However, this strategy, too, has never been taken for a similar reason.

Under this unique legal circumstance, the most critical question that is also the focus of this paper is how then quasi-states conduct quasi diplomacy with other states in the absence or lack of all those accesses to international fora and law. Unfortunately, this is the part where the existing literature is missing. No theory has been developed to explain the political consequences of this legal circumstance to understand the quasi diplomacy of these states for their survival. In terms of the purpose of this research, this paper, therefore, develops argument that by perceiving the common characteristics following the separation process with the parent state, quasi-states are not only legally weak but also politically weak at least in three important ways, such as in relations with its parent state, patron states, and domestic audience.

First, the quasi-state is weak due to the pressure from the parent states. The parent state here is defined as the state that was left by the quasi-state and still pursues unification with the quasi-state. Parent state, in this regard, is the most vocal in opposing international recognition of the quasi-state, as can be seen in most cases of the formation of quasi-state, such as China's pressure to Taiwan, Serbia's pressure to Kosovo, and Georgia's pressure to Abkhazia 
and South Ossetia. In terms of power relations, however, the parent state is more powerful than the quasi-state because, as a sovereign state, the parent state accepts recognition, rights, and status similar to other sovereign states. As mentioned earlier, quasi-state emerged from a secessionist movement of the parent state, and thus principally, it is against the internationally accepted norm of territorial integrity. In international society, therefore, the status of the quasi-state is weak, and the parent state could conduct diplomacy to prolong this quasi status by pressing other states not to grant any recognition to this secessionist state. This extreme case of this circumstance is when the parent state has an international reputation, such as China, who happens to be the permanent member of the UNSC, and thus, the country has the power to veto Taiwan's membership. In addition, the parent state, as it is previously the one that has a monopoly over the legitimate use of violence, is also stronger militarily compared to the quasi-state. Therefore, parent states often threaten to use force to gain the quasi-state back to their integral territory. Again, the extreme case is when the parent state is also powerful compared to other states, and thus other countries would think twice to go against the will of the parent state.

Second, the quasi-state is also weak due to the pressure from the patron states. Patron states here are defined as states who provide security umbrella or political support for the quasi-state. The quasi-state is weak in this regard because, in exchange for this support, the quasi-state needs to align its policies with that of taken by the patron states. By perceiving the limited recognition and diplomatic relations available to quasi-state, the patron state is a valuable partner that needs to be maintained. In the case of Taiwan, for example, its patron state could be perceived to be the United States. Although US-RoC Mutual Defense Treaty ended in 1980 after the US normalized its diplomatic relations with the PRC, the United States continued its cooperation with Taiwan under the framework of Taiwan Relations Act in which the US mentioned that it would "consider any effort to determine the future of Taiwan by other than peaceful means...will make available to Taiwan such defense article and defense services in such quantity as may be necessary to enable Taiwan to maintain a sufficient self-defense capability"
(Huang, 2010). This article, therefore, maintains the US security umbrella for Taiwan as enhanced by continuous arm sale, joint military cooperation, and bilateral defense talk.

Finally, the quasi-state is weak due to pressure from the domestic audience. The status of quasi-state is dilemmatic and divisive among the domestic audiences since it leads to two or more open-ended results, whether it gives up its struggle and returns to the parent state or continues to fight for international recognition. Any foreign policy toward the first end will meet the opposition of the independence group and vice versa. Pressure from the domestic audiences would tend to be higher in the case of democratic states facing territorial disputes. It is due to nature of territorial conflicts which tend to provoke nationalism among the domestic audience to defend the disputed territory and the nature of democratic states in which interstate dispute is more visible to local audience through the availability of information for the public (Putnam, 1998; Goddard, 2010; Fearon, 1994; Pertiwi, 2014). Besides, there might be an argument that political weakness, as mentioned above, could also occur in any recognized state. However, the occurrence is not by the system, indicating that it is not as persistent as those faced by quasi-states. Also, pressures for recognized states from the international level tend to vary depending on the issue. Meanwhile, the major pressure for quasi-states at all times is from the parent and the patron states.

Following these legal and political consequences, which all lead to the legal and political weaknesses of quasi-state, the diplomacy of quasi-state, consequently, would be more or less similar to the diplomacy of weak states. First of all, in response to the legal weaknesses in which quasi-states have limited access to most first track diplomacy, quasi-states would be a type of actor that would utilize multitrack diplomacy to gain maximum benefit. Multitrack diplomacy refers to the diplomacy strategy which is not only conducted officially between government to government or in the so-called first track but also unofficially, in the so-called non-first track. John McDonald suggests that there are nine possible tracks, but they are often simplified to be two tracks, in which the second covers all informal tracks from one and a half (partly formal with participation both from government and non-government actors), second track to 
third track (Chigas, 2003). In principle, multitrack diplomacy is used in the complex dispute in which first track diplomacy stalled, and parties need another avenue that is more open and less judgmental to maintain communication channel and to exchange more in-depth perspective in their capacity instead of as government representative which subject to many constraints (Chigas, 2003).

Meanwhile, in response to the political weaknesses, IR literature has extensively discussed the diplomacy of weak states, which could be categorized into several categories. The classical IR theories suggested that weak states could adopt balancing or bandwagoning strategy. Balancing refers to the approach to "balance against a perceived potential adversary either internally by shifting resource allocations to strengthen its defensive capability, or externally, by cooperating with another state that fears the same potential adversary" (Roy, 2005). Bandwagoning, on the contrary, refers to state strategy to align "with the threatening country to avoid being attacked by it" (Walt, 1987; Roy, 2005). However, more recent literature, drawing from non-western states' experiences, argues that weak states also have the option for hedging. Hedging refers to the strategy "to enable states to deal with uncertainties in their partner' future behavior by relying on a basket of policy tools that, while helping to promote bilateral cooperation, also entails

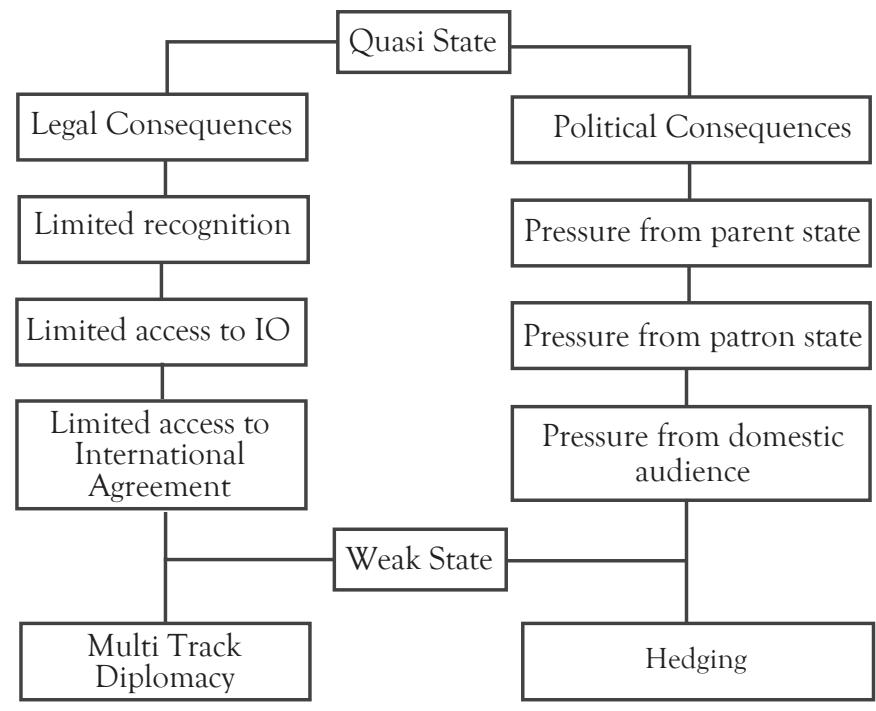

Figure 1. The Model of the diplomacy of Quasi State (Modified from various sources. See: deLisle, 2011; Henckaerts, 1996; Dijxhoorn, 2017; Chiang, 2018; Chigas, 2003; Roy, 2005; Walt, 1987). competitive" elements aimed at preparing themselves against potential security threats posed by their partners (Hiep, 2013). In essence, hedging is a strategy to keep “open more than one strategic option against the possibility of a future security threat (Roy, 2005). Hedging is commonly done by "establishing links with other large outside powers as counterweights" or by engaging the threatening power in international institutions (Roy, 2005). By perceiving the minimal options possessed by quasi-state, hedging is a more favorable option. As summarized in a model, therefore, the diplomacy of quasi-state could be seen as follows:

\section{RESULT AND ANALYSIS THE CASE STUDY OF TAIWAN IN THE SOUTH CHINA SEA}

Concerning the analytical framework of the diplomacy of the quasi-state explained above, this part will begin applying the model to the case study of Taiwan in the South China Sea disputes by explaining the context of the South China Sea disputes firstly. As mentioned earlier, South China Sea disputes are among the most contentious disputes in Southeast Asia. This dispute involves five states (Malaysia, Brunei Darussalam, Vietnam, the Philippines, and China) and one quasi-state, Taiwan, over the semi-enclosed sea surrounded by these states. The South China Sea consists of four main islands, i.e., the Spratlys, Paracels, Macclesfield Bank, and Pratas Islands. Some people in states claim partly or wholly the land features of the South China Sea, while others claim these features together with the surrounding waters. The basis for this claim itself varies across parties, in which some based their claim on geographical proximity while some other based on historical evidence. In either case, the strategic importance of the South China Sea, as mentioned earlier, has made the dispute more complicated. The South China Sea is not only crucial for its symbolic reason as part of states' claimed national territory but also its economic and strategic reasons.

The South China Sea dispute first erupted in 1974, when China occupied the Paracels islands amid the Cold War (Fravel, 2008; Garver, 1992). China feared that Soviet-supported by North Vietnam would seize the Paracels, and thus made the first move to grab the islands. The deteriorating relations between the two, the oil crisis, 
and the UN call for maritime delimitation along with the development of the UNCLOS resulted in another clash in 1988 (Pertiwi, 2014). There had been an unofficial regional initiative by the Indonesian government in collaboration with Canadian International Developmental Agency CIDA) to create Workshop on Managing Potential Conflicts in the South China Sea (WMPC-SCS) in 1990 to facilitate track two diplomacy among claimant states in the South China Sea. This workshop was successful in pushing ASEAN to adopt Declaration on the South China Sea, declaring ASEAN position in the dispute and its call for peaceful means, self-restraint, and cooperation among disputants. This workshop was also successful in bringing together China and Taiwan in the same table for continuous dialogue in the dispute. However, by the withdrawal of the US from the Philippines and that China became more powerful, another incident occurred in which China made the first move to the Philippines' claimed Mischief Reef in 1995. As a response, ASEAN issued the Declaration on the Code of Conduct in the South China Sea agreed in 2002 in which China was a party. While this declaration has contributed to the relative peace since 2002 with states continue working in translating the declaration into Code of Conduct, the rise of China and the UN call for submission of maritime delimitation of continental shelf have increased the tension in the disputed area along with countries competing to submit their claim to the UN and reinforcing their presence in the disputed territory. The tension peaked in the standoff in the Scarborough shoal between China and the Philippines in 2012. While no open military confrontation occurred, many recognized the different dynamics in the dispute since this period owing to the rising power of China which widened the power asymmetry among disputants, increased misperception and distrust, and provoked other regional powers to interfere in the disputes.

With the complexity of the dispute and the significant role of China, Taiwan's participation in the dispute is interesting as to why small quasi-state such as Taiwan maintains its claim in the dispute and how it survives the dispute. First of all, Taiwan has a strategic interest in the dispute. As a party claiming to be the legitimate representative of China, Taiwan's claim in the South China
Sea is similar with that of mainland China, in which they based its claim on the Location Map of the South China Sea Islands issued by Taiwan when it was still in power in mainland China in 1947 (Wang, 2010). This map illustrated the South China Sea area as bounded by the 11 dashed line up to four degrees north latitude (Ministry of Foreign Affairs, 2016). After the end of the Civil War along with the PRC taking over the government in the mainland, China under the PRC, continued its claim based on this map only by eliminating two lines in the Gulf of Tonkin and then making it a nine-dashed line (Kuok, 2015). The map itself was the result of the historical records far back beyond 200 BC of the Han Dynasty which has sent a delegation to the area and other historical records demonstrating fishermen activities in the area. The reference of this map is among the most debated issue in the dispute as it covers almost the entire South China Sea and thus overlaps with all territories claimed by other states. Both Taiwan and China never clarify what they mean with the dashed line. Many also criticize the claim as also problematic as it is based on historical records instead of international law. Regardless of this debate, however, one crucial point is that both China and Taiwan defend their claimed territory because, in their version, it has been part of their integral territory since ancient times. In its official document, Taiwan asserted that islands in the South China Sea "were first discovered by the ancient Chinese", "were firstly named by the Chinese people and government", "were firstly used by the ancient Chinese", "were first incorporated into national territory by the early Chinese", and "were first administered by the early Chinese" (Ministry of Foreign Affairs, 2016). Thus, as the legitimate representative of China, Taiwan has to maintain this claim as the symbol of its sovereignty and territorial integrity. It is well understood as theories on territorial disputes demonstrate that territorial dispute is among the most contentious dispute and often leads to war since it is related to territorial attachment which often provokes nationalism among domestic audiences (Diehl \& Goertz, 1988). Some even argue further that it is the nature of humans as vertebrates to claim territory (Senese \& Vasquez, 2003; Vasquez, 1993). Therefore, no matter how small the disputed territory and how weak the claimant 
state is, it would tend to defend their claimed territory.

However, sovereignty is not the only factor behind Taiwan's claim. Geopolitics, military, economic, and domestic factors also matter. Ian Easton (Easton, 2016) has highlighted the strategic positions of the South China Sea for Taiwan. Currently, Taiwan has occupied over Pratas and Itu Aba. These two islands have contributed to Taiwan's defense interest. According to Easton, "Pratas Island is an excellent location to monitor key PLA units which could threaten Taiwan's security and Itu Aba because it offers Taiwan the ability to observe Chinese air and naval movements through the distant reaches of the South China Sea" (Easton, 2016a). Taiwan's presence in the South China Sea could not be separated from its international status itself. Taiwan's national security and sovereignty are threatened due to its sovereignty conflict with the People's Republic of China (PRC). Therefore, any military activities conducted by the PRC should be monitored and reported to the U.S. Since Pratas, and Itu Aba have strategic locations, these two islands contributed to the safety and sovereignty of Taiwan. Moreover, Easton also pointed out the economic significance of the South China Sea for Taiwan. It works as markets and suppliers in Europe and the Middle East for Taiwan (Easton, 2016). Taiwan imported more than 90 percent of its oil from the Middle East, and thus Taiwan was not only interested in securing freedom of navigation in the disputed area, but also exploring potential oil resources in its claimed territory. Finally, Taiwan, as the world's major fish-producing country, also has interests in the rich fishing ground in the area.

\section{THE DIPLOMACY OF TAIWAN AS A QUASI-STATE IN THE SOUTH CHINA SEA DISPUTE}

By possessing these strategic interests in the dispute, Taiwan needs to conduct diplomacy to secure its strategic interests in the South China Sea. However, its status as a quasi-state implies that it has legal and political weaknesses in which it not only has limited access to international law and other first track mechanisms, but it also faces pressures from parent-state, patron state, and domestic audience. The diplomacy of Taiwan as a quasi-state to deal with the legal weaknesses in this regard would include maximizing the small opportunities in the first track and exploit other opportunities in the second track in a strategy called multitrack diplomacy. In dealing with political weaknesses, Taiwan would have the option to adopt a hedging strategy. The combination of this strategy would be explained as follows.

\section{THE TAIWAN'S FIRST TRACK DIPLOMACY}

The first track of diplomacy involves government participation through formal bilateral and multilateral forums to solve potential conflicts. In this case, Taiwan's diplomacy could be categorized into two strategies: one being strategic to deal with legal weaknesses and the other being strategic to deal with political weakness.

Legally, Taiwan still has access to UNCLOS and its judicial body, ITLOS. However, its political weaknesses, mainly resulting from the pressure of the parent states, leave Taiwan limited access to international and regional first track mechanism, such as ASEAN related meetings, Declaration on the Conduct of Parties in the South China Sea (DoC), cooperation such as Joint Seismic Undertaking between China-Vietnam-the Philippines (JMSU), and even bilateral diplomacy with other claimant states due to other's adherence to One China Policy. Taiwan, however, needs to demonstrate its resolve in the dispute if it aims to maintain its existence in an international level and if it seeks to demonstrate its sovereignty over the claimed territory. Pressure from domestic audiences over the ruling government to defend its claimed territory also increases the necessity for Taiwan to maintain its presence in the dispute. Taiwan's strategy in this context is the compromise between self-restraint and its effort to reinforce its claim in the dispute. It results in Taiwan's dominant policies which tend to be in the forms of statements rather than actions, and also reaction rather than provocation. It could be seen clearly in particular after Taiwan occupied Itu Aba and equipped the islands with military installation, and then Taiwan made no further move in the disputes.

Amidst the rising tensions between Vietnam and China in the Spratly in 1988, Taiwan created national task force which led to the issuance of the 1993 Policy Guidelines for the South China Sea which reemphasized its claim that the four islands and the historic water limit belonged to Taiwan and that it was willing to cooperate 
with other claimant states for the dispute management and maritime cooperation in the area (Kao, 2014a). After the Mischief Reef incident and other states' responses to it by enhancing their presence in their claimed territory, Taiwan clearly stated that it would not increase its military presence in the disputed area (Kao, 2014). Instead, Taiwan adopted the Law on the Territorial Sea and the Contiguous Zone of the ROC and the Law on the Exclusive Economic Zone and the Continental Shelf of the ROC in January 1998 (Hickey, 2016). Taiwan strongly opposed it when Malaysia occupied Investigator Shoal and Erica Reef in 1999, but again it was delivered in an official statement and domestic legislation to reiterate its baseline of the territorial sea $(\mathrm{Lu})$. Similar policy was adopted when tension arose in 2009 along with Malaysia and Vietnam making joint submission of their continental shelf to the $\mathrm{UN}$, and later Taiwan demonstrated its resolve through official statement by MOFA reemphasizing that the four islands chain and the surrounding waters belong to Taiwan and that "any sovereignty claims over or occupation of these islands under any reason or any means by any other country shall be null and void" (Lu). By the continued tension in the South China Sea which peaked in the standoff between China and the Philippines and Taiwan was still excluded from any diplomatic processes, Taiwan decided to play a more significant role as an honest broker in the dispute by proposing a South China Sea Peace Initiative which principally promoted the principles of "safeguarding sovereignty, shelving disputes, pursuing peace and reciprocity, and promoting cooperation" among states in the dispute (Ministry of Foreign Affairs, 2016). This initiative is quite similar to the East China Sea Initiative that was also offered by Ma. The roadmap of this initiative consists of three stages:

"In the short term, jointly shelving the disputes and launching multilateral dialogue and consultations, integrated planning in the midterm; and over the long term, the establishment of zonal development through bilateral or multilateral cooperation through bilateral or multilateral cooperation leading to fair and reciprocal win-win results." (Ministry of Foreign Affairs, 2016).
This initiative seemed to be the most salient effort made by Taiwan to be listened to and existed among other states while maintaining self-restraint. This initiative has earned some success with Taiwan, and the Philippines later signed "Agreement Concerning the Facilitation of Cooperation on Law Enforcement," which in principle shelved their bilateral disputes and developed fisheries cooperation. It also set up guidelines among the two in favor of addressing maritime disputes. Both have overlapping claims over their EEZ. Thus, to provide a legal framework for capacity building and conflict resolution, this bilateral agreement might support Taiwan's weak status. While other impacts need to be identified, this initiative was evidence of Taiwan's strategy in dealing with its legal weaknesses. One substantial blowback for Taiwan's legal weakness, however, was the recent International Arbitration ruling over the dispute between China and the Philippines. Although Taiwan was not a party to the ruling, similar claim between China and Taiwan made the arbitration issue its ruling on Itu Aba stating that it is not an island, but a rock, and thus it could not be entitled maritime zone. Although it has provoked a strong protest from Taiwan on the same day of the announcement of the ruling, Taiwan's legal weakness hindered it to lodge a formal protest and propose its case in formal processes. Thus, to demonstrate its resolve, President Ma made a historical visit to Taiping Island in 2016. It marked a strong claim that this area was not just a "rock" but an "island" reversing arguments from the Philippines (Jing, 2016).

Taiwan's diplomacy strategy is not only a result of its legal weakness in which it needs to compromise its legal weakness and its necessity to defend the claimed territory, but also a result of its political defects in which it also needs to compromise the pressure from parent state, China, the pressure from the patron state, the United States, and the pressure from domestic audience. Taiwan's strategy, in this context, imitates a hedging strategy. To elaborate the case, pressure from the parent state, China, was not only in the form of pushing other countries to adhere to One China Policy, but also in the way of its repeated call for cooperation with Taiwan in the dispute. As parties claiming to be representative of China, both 
China and Taiwan must maintain a similar claim and position in the dispute. In its call, China asserted that safeguarding the country's sovereignty and territorial integrity as well as the overall interests of the Chinese nation should be a common obligation of compatriots of the two sides" (Tiezzi, 2014). This call has undeniably created domestic pressure between groups supporting and against cross-strait cooperation. The two main parties, DPP and KMT differed significantly on this issue, which adds to domestic tension (Kao, 2014). Externally, this call also created a domino effect in the form of US pressure as Taiwan's patron state in this regard. The United States is not a party to the dispute, but as a global maritime power, it has a stake on the freedom of navigation in the South China Sea. Along with China's Excessive claim in the dispute, the US has repeatedly called for China's clarification on the nine-dashed line and ensured China abide by the UNCLOS. In this regard, the US pressed Taiwan to clarify its claim in the dispute and follow international law in the hope that this departing position would undermine China's claim (Kuok, 2015). These multidirectional pressures have led Taiwan to opt for a more open option in the form of hedging. On the one hand, Taiwan seems to band-wagon to China as its main priority is to maintain cross-strait relations. Although it will vary depending on which party leading the government, the divisiveness of this issue makes extreme changes less likely. Moreover, Taiwan, again, has a similar claim with China. On the other hand, Taiwan also balances against China through its internal and external balancing with the United States. The balancing act is more of the result of domestic pressure from those advocating for more independent Taiwan and pressure from the US as Taiwan's closest ally.

The bandwagoning act could be seen in Taiwan's consistent policy for being silent and tranquil in response to China's behaviour in the South China Sea. Upon the Mischief Reef incident and subsequent China's move in the disputed area, Taiwan made no protest about it. However, when Malaysia occupied Erica, followed by Vietnam and the Philippines, which strengthened the position in the disputed area, Taiwan made a strong protest and reinforced its claim in the dispute (MOFA, 1997; MOFA, 1999). Similarly, when China continuously developed artificial islands in the disputed area, Taiwan defended it by stating that "international law does not forbid such actions” (Hickey, 2016). However, when Vietnam and Malaysia made a joint submission to the UN, Vietnam issued its law on the sea. Nonetheless, when the Philippines renamed the South China Sea to the West Philippines Sea, Taiwan "expresses its serious concern and firm opposition" and "rejects such moves" (MOFA, 2009; MOFA, 2012; MOFA, 2013). Taiwan, however, was not purely bandwagoning to China. The pressure from the US and domestic audience have pushed Taiwan to keep some distance from China. The US called for Taiwan to clarify its claim and internal demand from pro-independent groups which have contributed to Taiwan's balancing act. While Taiwan maintains self-restraint policy by demonstrating its presence through its statement instead of action, it could be perceived as the shifting tone of Taiwan's statement from the 1990s to the present. From the beginning of the dispute, Taiwan's claim is exactly similar to China emphasizing its claim in the entire South China Sea and that its claim is based on historic water noted in historical evidence. In its statement, Taiwan's claim is as follows:

"In terms of history, geography, international law, and facts, the Nansha Islands [Spratly Islands], Shisha Islands [Paracel Islands], Changsha Islands [Macclesfield Islands], Tungsha Islands [Pratas Islands] are part of inherent territory of the Republic of China; the sovereignty over those islands belongs to the Republic of China. The South China Sea area within the historic water limit is the maritime area under the jurisdiction of the Republic of China, where the Republic of China possesses all rights and interests." (Hu \& McDorman, 2013).

This statement was repeated in each response to other claimants' activities in the disputed area. However, along with the US pressure to clarify its claim and the shifting power in the government, Taiwan's claim has shifted by no more emphasizing the historical base. It stated repeatedly that "The Spratly Islands [Nansha Islands, 南 沙群島], Paracel Islands [Xisha Islands, 西沙群島], Macclesfield Bank [Zhongsha Islands, 中沙群島] and the Pratas Islands [Dongsha Islands, 東沙群島], as well as their surrounding waters, are inherent parts of Republic of China [ROC] territory" (Kuok, 2015) whether it 
indicates that Taiwan began to base its claim on UNCLOS as it always states to be remained being studied. The latest development, however, concerning the International Arbitration ruling system reveals that Taiwan is clearer in its position not to cooperate with China, even when the ruling system disadvantages Taiwan on the status of Itu Aba.

\section{THE TAIWAN'S SECOND TRACK DIPLOMACY}

The second track diplomacy focuses on the tracks outsid the government parties. The variable might vary depending on the purpose of the state's goal. This paper classified the second track diplomacy with the indication that Taiwan can utilize it apart from the government's track. This track is essential for Taiwan as a quasi-state, in which the country has been excluded from any official dialogue discussing South China Sea issues. In the management conflict, the role of the second track diplomacy might help bridge the barriers that could not be solved through the government's channels. It stressed the role of third-party that might come in various forms.

For Taiwan, second track diplomacy has different characteristics. In the past, Taiwan tended to co-opt NGOs to speak for government interests. However, in the present, Taiwan prefers to characterize its diplomacy as people-to-people diplomacy (minjian waijiao) as it gives more freedom for the non-state actors to build network horizontally and internationally with other non-state and state actors (Lang, 2014). This paradigm shift is the result of Taiwan's focus on increasing representativeness at the international level and its effort in reducing problems of interstate relations as a quasi-state. In this sense, the government plays its role by cooperating with the NGOs through assistantship or authorization on areas under consideration (Lang, 2014). Regarding South China Sea disputes, Taiwan seems to employ both the past and present second track diplomacy. The first could be perceived in the adoption of the first and half-track diplomacy, where the government facilitates the involvement and participation of non-state actors in the South China Sea discussion forums. Meanwhile, the second could be perceived in the more independent involvement of Taiwan's civil society organization in the South China Sea discussion.
The first one and half-track diplomacy is the Workshop on Managing Potential Conflicts in the South China Sea (WMPC-SCS). WMPC-SCS is not Taiwan's initiated discussion forum. Yet, it is among the initial forums which give the only space for Taiwan's involvement in discussing the dispute, and Taiwan has taken this opportunity to participate actively in the forum. WMPC SCS was initiated by Indonesian diplomat, Hasyim Djalal in 1989 aiming to manage potential conflicts through dialogue and mechanism of cooperation and exploration between the claimants (Song, 2010a). The workshop invited scholars and governments from disputed countries, and their presence counted as personal or private rather than official representatives. Therefore, Taiwan has partaken the forum since 1991, together with delegations from China. Since Taiwan was excluded from any formal dialogue mechanism, WMPC-SCS helped serve Taiwan's interest and voice in South China Sea disputes. This forum was not designed to resolve the conflict but rather, to create a sense of community by managing the disputes through cooperation and confidence-building measure (Song, 2010). Although tension came on and off, the workshop at least contributed to common understanding among disputed countries regarding the importance of the South China Sea. The most significant milestone that has been reached with China and Taiwan participation is both sides agree to work together and come up with a joint SCS project proposal, namely The China-Taiwan South-East Asia Network for Education and Training (SEA-NET) which was adopted on 2009 (Song, 2010). This achievement shows the significance of the second track diplomacy for less powerful states such as Taiwan to preserve its strategic interests and at least to maintain its involvement in dispute management. WMPC-SCS, however, could not be the only second track diplomacy for Taiwan in the South China Sea. Regardless of the achievement mentioned above, there is still any limitation for Taiwan to maneuver in the meeting with China, which banned Taiwan from hosting any related meeting to the workshop (Li, 2016a).

It is for this reason that in 2015, President Ma Ying-jeou announced the South China Sea Peace Initiative (SCSPI). In addition to being the first track diplomacy, this initiative gave room for non-state actors 
to participate in the various cooperation initiatives. In essence, SCSPI calls for claimants to perform self-restraint, respect international law, shelving sovereignty dispute, and cooperate in maritime resources, environment, scientific research, transnational crime, and disaster relief (Li, 2016). This initiative was Taiwan's successful East Asia Peace Initiative, which could bring the disputants to cooperate in fisheries areas. This initiative was perceived to offer a fewer risk for claimant states compared to other actions that have been developed to manage the dispute in the South China Sea. However, the progress and implementation of this initiative remained to be identified. At this point, SCSPI is a case of how Taiwan made efforts to enlarge its participation through the second track diplomacy. However, the progress and implementation of this initiative remained to be identified. At this point, SCSPI is a case of how Taiwan made efforts to enlarge its participation through the second track diplomacy.

The more independent second track diplomacy used by Taiwan might be able to be perceived in academic forums such as the International Law Association, American Society in International Law (ILA-ASIL) and Asia-Pacific Research Forum, for instance. This forum generally aims for the development of international law, although it does not explicitly address the issue of the South China Sea like WMPC. Nevertheless, it is also useful as a stage for discussing the aspect of international law from disputed issues through academic and scholarly exchanges. It is also in ILA-ASIL Asia Pacific Research Forum convened in Taipei in 2015 that President Ma introduced this South China Sea Peace Initiative Roadmap explained above (Jing, 2016).

\section{CONCLUSION}

Based on the current findings, this research concludes that there is a particular pattern of how quasi-state conducts diplomacy in an international dispute resulting from its certain circumstances. By using the theoretical framework of quasi-state, it is apparent that quasi-state suffers from both legal and political weaknesses including limited access to an international organization, limited access to an international agreement, and insufficient recognition from other states. Meanwhile, the latter includes pressure from parent-states, pressure from patron states, and pressure from the domestic audience. To deal with the first weakness, quasi-state has dominantly demonstrated multi-track diplomacy as its strategy to other states in international disputes. It indicates that a quasi-state prefers to maximize its non-first track diplomacy to represent its position and achieve its interest. In the case of Taiwan, the adoption of multitrack diplomacy appears, for example, in its participation in the WMPC-SCS. This research, however, found that even in the second track diplomacy, Taiwan still encounters a severe challenge when it comes to dealing with China or when it wants to transfer this initiative to the first track diplomacy. Meanwhile, to deal with the second weakness, the quasi-state has dominantly adopted hedging strategy, which indicates the cooperation with the more significant power to protect its interest rather than fighting against it. Hedging, in this sense, is conducted by Taiwan in its relations with the United States. By observing this trend and revealing the fact that quasi-state requires support from as many states as possible, this paper suggests that Taiwan could also initiate closer relations with other sympathetic countries or other quasi-states in addition to its parent and patron-states.

\section{REFERENCE}

Ba, A. D. (2011). Staking claims and making waves in the South China Sea: How Troubled Arethe Waters? Contemporary Southeast Asia, 33(3), 269-291. doi:10.1355/cs33-3a

Buszynski, L. (2012). The South China Sea: Oil, Maritime Claims, and U.S. China Strategic Rivalry. The Washington Quarterly, 35(2), 139-156. doi: 10.1080/0163660X.2012.666495

Caspersen, N. (2012). Unrecognized states: The struggle for sovereignty in the modern. Malden: Polity Press.

Central Intelligence Agency. (2018). The world fact book: Taiwan. Retrieved September 1, 2019, from https://www.cia.gov/li brary/publications/the-world-factbook/geos/tw.html

Chiang, F. (2018). The One-China Policy: state, sovereignty, and Taiwan's international legal status. Amsterdam: Elsevier.

China, M. o. (2013). Ministry of Foreign Affairs of Republic of China. Retrieved September 1, 2019, from https://www.mo fa.gov.tw/en/News_Content.aspx?n=0E7B91A8F BEC4A94\&s=9D31DA5243EEFED1

De Castro, R. C. (2009). The US-Philippine alliance: An evolving hedge against an emerging china challenge. Contemporary Southeast Asia, 31(3), 399-423. doi: 10.1355/cs31-3b

De Lisle, J. (2011). Taiwan: Sovereignty and participation in international organizations. Philadelphia: Foreign Policy Research Institute.

Diana, C. (2003, August). Track II (Citizen) Diplomacy. Beyond Intractibility. Retrieved September 1, 2019, from https://w ww. beyondintractability.org/essay/track2_diplomacy 
Diehl, P. F., \& Goertz, G. (1988). Territorial Change and Militerized Conflict. Journal of Conflict Resolution, 32(1), 103-122. doi: 10.1177/0022002788032001005

Dijxhoorn, E. (2017). Quasi-state entities and International Criminal Justice: Legitimizing narratives and counter narratives. London: Routledge.

Easton, I. (2016, October 17). Challenges Facing Taiwan in the South China Sea. Virginia: Project 2049 Institute.

Fearon, J. D. (1994). Domestic Political Audiences and the Escalation of International Disputes. The American Political Science Review, 88(3), 577-592. doi:10.2307/2944796

Florea, A. (2014). De facto states in international politics (1945 2011): A new data set. International Interactions, 40(5), 788-811. doi: 10.1080/03050629.2014.915543

Fravel, M. T. (2008). Strong Borders Secure Nation: Cooperation and Conflict in China's Territorial Disputes. Princeton: Princeton University Press.

Fravel, M. T. (2011). China's Strategy in the South China Sea. Contemporary Southeast Asia, 33(3), 292-319. doi: $10.1355 / \mathrm{cs} 33-3 b$

Garver, J. W. (1992). China's Push Through the South China Sea: The Interaction of Bureaucratic and National Interests. China Quarterly, 999-1028.

Goddard, S. E. (2010). Indivisible Territory and the Politics of Legitimacy. Cambridge: Cambridge University Press.

Goldstein, L. (2011). Chinese naval strategy in the South China Sea: An Abudance of Noise and Smoke, but Little Fire. Contemporary Southeast Asia, 33(3), 320-347. doi: $10.1355 / \mathrm{cs} 33-3 \mathrm{c}$

Greer, A. (2016). The South China Sea is really a fishery dispute. Retrieved August 29, 2019, from The Diplomat: https://thediplomat.com/2016/07/the-south-china-sea-is-re ally-a-fishery-dispute/

Henckaerts, J. M. (. (1996). The International Status of Taiwan in the New World Order: Legal and Political Considerations. London: Kluwer Law International.

Hickey, D. (2016). In the Eye of the Typhoon: Taiwan and the Growing Dispute in the South China Sea. The Political Economy of China-Latin America, 40(4), 731-751.

Hiep, L. L. (2013). Vietnam's Hedging Strategy against China since Normalization. Contemporary Southeast Asia, 35(3), 333-368. doi: 10.1355/cs35-3b

Hsieh, P. L. (2007). An unrecognized state in foreign and international court: The case of the Reoublic of China on Taiwan. Michigan Journal of International Law, 28(4), 765-814

Hu, N.-T., \& McDorman, T. (Eds.). (2013). Maritime Issues in the South China Sea: Troubled Waters or A Sea of Opportunity. Oxford: Routledge.

Huang, A. C.-c. (2010, February 16). The United States and Taiwan's Defense Transformation. Retrieved April 10, 2018, from http://www. brookings.edu/opinions/the-unit ed-states-and-taiwans-defense-transformation/

Jackson, R. H. (1990). Quasi-States: sovereignty, international relations, and the third world. Cambridge: Cambridge University Press.

Jing, B.-J. (2016). Taiwan and Southeast Asia: opportunities and constraints of continued engagements. Maryland Series in Contemporary Asian Studies, 2016(2), 44-45.
Johnson, A. N. (2012). A bilateral analysis of the South China Sea Dispute: China, the Philippines, and the Scarborough Shoal. (Unpublished master's thesisn). Florida International University.

Kao, S. S.-f. (2014). Scarborough Shoal Dispute, China's Assertiveness, and Taiwan's South China Sea Policy. International Journal of China Studies, 5(1), 153.

Kim, S. P. (1998). The South China Sea in China's Strategic Thinking. Contemporary Southeast Asia, 19(4), 369-387.

Kolossov, V., \& O'Loughlin, J. (1998). Pseudo-states as harbingers of a post-modern geopolitics: The example of the Trans-Dniester Moldovan Republic (TMR). Geopolitics, 3(1), 151-176. doi: 10.1080/14650049808407612

Kolsto, P. (2006). The sustainability and future of unrecognized quasi-states. Journal of Peace Research, 43(6), 723-740.

doi: 10.1177/0022343306068102

Kuok, L. (2015). Tides of Change: Taiwan's evolving position in the South China Sea And why other actors should take notice. Washington DC: Brookings Institute.

Lang, B. (2014). Off the beaten track? Taiwan's changing ' track-two diplomacy' after democratisation - and its pitfalls.

Lemke, D. (2017, October). The emergence \& survival of de facto states. Retrieved May 6, 2018 from Penn State University: https://sites.psu.edu/pssi/files/2017/10/Lemke PeaceSci ence 2017-s5f4gs.pdf

Li, C.-p. (2016). The South China Sea peace initiative in a transitional security environment. American Journal of Chinese Studies, 23(1), 119-134.

Lu, Y.-c. (n.d.). The South China Sea and Great Power Politics: Implications for U.S.-China-Taiwan Relations. Stimson Center. Retrieved April 10, 2018, from https://www.stim son.org/sites/default/files/fileattachments/south china sea and great power poli tics_yeh-chung_lu_0_0.pdf

McConnel, F., Moreau, T., \& Dittmer, J. (2012). Mimicking state diplomacy: The legitimizing strategies of unofficial diplomacies. Geoforum, 43(4), 804-814. doi: 10.1016/ j.geoforum.2012.01.007

Ministry of Foreign Affairs. (2016). Peace in the South China Sea, National Territory Secure Forever: Position Paper on ROC South China Sea Policy. Taipei: David Y.L. Lin.

MOFA. (1997). In response to the election held by the Government of the Philippines, for the village chief in the so called "Kalayaan Islands". Retrieved April 10, 2018, from https://w ww. mofa.gov.tw/en/News Content.aspx?n=0E7B91A8F $\mathrm{BEC} 4 \mathrm{A94} \& \mathrm{sms}=220 \mathrm{E} 98 \mathrm{D} 761 \mathrm{D} 34 \mathrm{~A} 9 \mathrm{~A} \& \mathrm{~s}=\mathrm{C} 4 \mathrm{E} 7 \mathrm{~F} 89$ FA4133436

MOFA. (1999). The government of the Republic of China lodges its protest against the recent illegal occupation of Investigator Shoal and Erica Reef in the Nansha Islands by the Malaysian government... Retrieved April 12, 2018, from https://ww w.mofa.gov.tw/en/News_Content.aspx? $n=0$ E7B91A8F BEC4A94\&sms $=220$ E98D761D34A9A\&s $=$ 941DC646752CFBE9

MOFA. (2009). The Ministry of Foreign Affairs of the Republic of China solemnly declares statement on the governments of Malaysia and Vietnam filed a Joint Submission to the Commission on the Limits of the Continental Shelf of the United Nations, extending the outer limits of their 
respective continental shelf 200 nautical miles beyond their shorelines. Retrieved April 10, 2018, from https://www.mo fa.gov.tw/en/News_Content.aspx?n=0E7B91A8F

BEC4A94\&sms $=220$ E98D761D34A9A\&s $=$

CD962A9AD6F1F16E

MOFA. (2012). The government of the Republic of China (Taiwan) reiterates its claim to sovereignty over the South China Sea and refuses to accept any unilateral action taken by other concerned parties. Retrieved April 12, 2018, from https://w ww.mofa.gov.tw/en/News_Content.aspx?n=0E7B91A8F BEC4A94\&sms $=220$ E98D761D34A9A\&s= 9292161706F31F1F

MOFA. (2013). The Republic of China (Taiwan) protests Vietnam law claiming South China Sea Islands. Retrieved May, 2018 from https://www.mofa.gov.tw/en/News_Content.aspx $? \mathrm{n}=0 \mathrm{E} 7 \mathrm{~B} 91 \mathrm{~A} 8 \mathrm{FBEC} 4 \mathrm{~A} 94 \& \mathrm{sms}=220 \mathrm{E} 98 \mathrm{D} 761 \mathrm{D} 34 \mathrm{~A} 9 \mathrm{~A} \& \mathrm{~s}=$ 9D31DA5243EEFED1

Notter, J., \& Diamond, L. (1996). Building Peace and Transforming Conflict: Multi-track Diplomacy in Practice. Occasional Paper (7), 1-19.

Pegg, S. (1998). De facto states in the international system. Vancouver: Institute of International Relations, University of British Columbia.

Pertiwi, S. B. (2014). The Rise of Territorial Disputes and the Stability of Southeast Asia. Washington DC: American University.

Putnam, R. (1998). Diplomacy and Domestic Politics: The Logic of Two-Level Games. International Organization, 42(3), 427-460.

Roy, D. (2005). Southeast Asia and China: Balancing or Bandwagoning?. Contemporary Southeast Asia, 27(2), 305-322.

Senese, , P., \& Vasquez, J. (2003). A Unified Explanation of Territorial Conflict: Testing the Impact of Sampling Bias, 1919-1992. International Studies Quarterly, 47(2), 277. doi: $10.1111 / 1468-2478.4702006$

Song, Y.-H. (2010). The South China Sea workshop process and Taiwan's participation. Ocean Development and International Law, 41(3), 253-269. doi: $10.1080 / 00908320.2010 .499296$

Storey, I. J. (1999). Creeping Assertiveness: China, the Philippines and the South China Sea Dispute. Contemporary Southeast Asia, 21(1), 95-118.

Storey, I. (2008, April 1). Conflict in the South China Sea: China's Relations with Vietnam and the Philippines. The Asia-Pacific Journal: Japan Focus, 6(4).

Sutter, R. (2010). The United States and China in Southeast Asia: conflict or convergence?. Southeast Asian Affairs, 2010(1), 44-59.

Swaine, M. D., \& Fravel, M. (2011). China's assertive behavior part two: Maritime Periphery, China Leadership Monitor No.35. Carnegie Endowment for International Peace, 06(24).

Taiwan Today. (2017). Taiwan ranks 15th in WEF Global Competitiveness Report. Retrieved September 1, 2018, from https://taiwantoday.tw/news. php? unit=2,6,10,15, 18\&post $=122232$

Thayer, C. A. (2011). The Tyranny of Geography: Vietnamese Strategies to Constrain China in the South China Sea. Contemporary Southeast Asia, 33(3), 348-369.
Thayer, C. A. (2012, August 19). ASEAN'S Code of Conduct in the South China Sea: A Litmus Test for Community-Build ing?. The Asia-Pacific Journal: Japan Focus, 10(34).

Tiezzi, S. (2014, May 15). Taiwan will not cooperate with China in South China Sea. Retrieved September 3, 2018 from The Diplomat: https://thediplomat.com/2014/05/tai wan-will-not-cooperate-with-china-in-south-china-sea/

Vasquez, J. A. (1993). The war puzzle. Cambridge: Cambridge University Press.

Walt, S. M. (1987). The origins of alliances. Ithaca: Cornell University Press.

Wang, F. (2018, February 23). Taiwan has world's 2nd-largest distant-water fishing fleet. Retrieved April 10, 2018, from Focus Taiwan: http://focustaiwan .tw/news/asoc/201802230023.aspx

Wang, K. H. (2010). The ROC's maritime claims and practices with special reference to the South China Sea. Ocean Development \& International Law, 41(3), 237-252. doi: 10.1080/00908320.2010.499282 